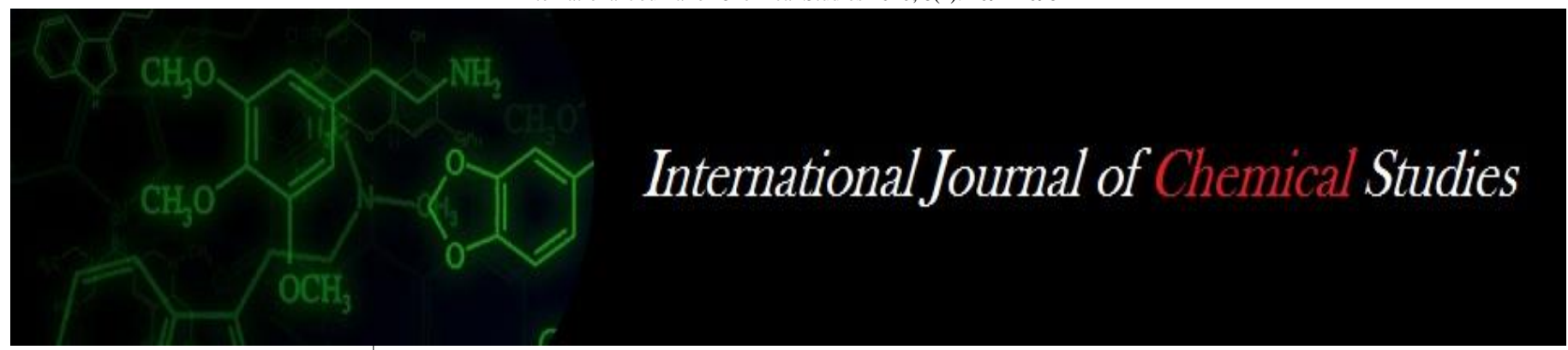

P-ISSN: 2349-8528

E-ISSN: 2321-4902

www.chemijournal.com

IJCS 2020; 8(2): 2694-2698

(C) 2020 IJCS

Received: 01-01-2020

Accepted: 04-02-2020

Tanmoy Shankar

Department of Agronomy,

M.S. Swaminathan School of

Agriculture, Centurion

University Technology and

Management, Paralakhemundi,

Odisha, India

\section{Mahua Banerjee}

Institute of Agriculture,

Visva-Bharati University,

Sriniketan, Birbhum,

West Bengal, India

\section{GC Malik}

Institute of Agriculture,

Visva-Bharati University,

Sriniketan, Birbhum,

West Bengal, India

\section{Sudarshan Dutta}

(1). International Plant

Nutrition Institute, South Asia

(East India and Bangladesh)

Program

(2). African Plant Nutrition

Institute, Benguerir, Morocco

Corresponding Author:

Tanmoy Shankar

Department of Agronomy,

M.S. Swaminathan School of Agriculture, Centurion

University Technology and

Management, Paralakhemundi,

Odisha, India

\section{Effect of nutrient management on growth, productivity and economics in rice based cropping system in lateritic soil of West Bengal}

\author{
Tanmoy Shankar, Mahua Banerjee, GC Malik and Sudarshan Dutta
}

DOI: https://doi.org/10.22271/chemi.2020.v8.i2ao.9156

\begin{abstract}
The experiment was conducted during 2014-2015 and 2015-2016 at farmers' field situated at Binuria village $\left(23^{\circ} 40^{\prime} \mathrm{N}\right.$ and $\left.87^{\circ} 37^{\prime} \mathrm{E}\right)$ of Birbhum district of West Bengal under the red and lateritic belt of West Bengal. The experiment was laid out in Randomized Block Design with three replication and twelve treatments in both during kharif and boro season. The plot size was $5 \mathrm{~m} \times 4 \mathrm{~m}$ and the treatment combinations are $\mathrm{T}_{1}-\mathrm{N}_{80} \mathrm{P}_{40} \mathrm{~K}_{40} \mathrm{Zn}_{25} \mathrm{~S}_{20}, \mathrm{~T}_{2}-\mathrm{N}_{40} \mathrm{P}_{40} \mathrm{~K}_{40} \mathrm{Zn}_{25} \mathrm{~S}_{20}, \mathrm{~T}_{3}-\mathrm{N}_{0} \mathrm{P}_{40} \mathrm{~K}_{40} \mathrm{Zn}_{25} \mathrm{~S}_{20}, \mathrm{~T}_{4}-\mathrm{N}_{80} \mathrm{P}_{20} \mathrm{~K}_{40} \mathrm{Zn}_{25} \mathrm{~S}_{20}$, $\mathrm{T}_{5}-\mathrm{N}_{80} \mathrm{P}_{0} \mathrm{~K}_{40} \mathrm{Zn}_{25} \mathrm{~S}_{20}, \quad \mathrm{~T}_{6}-\mathrm{N}_{80} \mathrm{P}_{40} \mathrm{~K}_{20} \mathrm{Zn}_{25} \mathrm{~S}_{20}, \quad \mathrm{~T}_{7}-\mathrm{N}_{80} \mathrm{P}_{40} \mathrm{~K}_{0} \mathrm{Zn}_{25} \mathrm{~S}_{20}, \quad \mathrm{~T}_{8}-\mathrm{N}_{80} \mathrm{P}_{40} \mathrm{~K}_{40} \mathrm{Zn}_{12.5} \mathrm{~S}_{20}, \quad \mathrm{~T}_{9}-$ $\mathrm{N}_{80} \mathrm{P}_{40} \mathrm{~K}_{40} \mathrm{Zn}_{0} \mathrm{~S}_{20}, \mathrm{~T}_{10}-\mathrm{N}_{80} \mathrm{P}_{40} \mathrm{~K}_{40} \mathrm{Zn}_{25} \mathrm{~S}_{10}, \mathrm{~T}_{-11}, \mathrm{~N}_{80} \mathrm{P}_{40} \mathrm{~K}_{40} \mathrm{Zn}_{25} \mathrm{~S}_{0}$ and $\mathrm{T}_{12}$-Control where as in boro season the treatment combinations are $\mathrm{T}_{1-}-\mathrm{N}_{120} \mathrm{P}_{60} \mathrm{~K}_{60} \mathrm{Zn}_{25} \mathrm{~S}_{20}, \quad \mathrm{~T}_{2}-\mathrm{N}_{60} \mathrm{~K}_{60} \mathrm{Zn}_{25} \mathrm{~S}_{20}, \quad \mathrm{~T}_{3}-\mathrm{N}_{0} \mathrm{~K}_{60} \mathrm{Zn}_{25} \mathrm{~S}_{20}, \mathrm{~T}_{4}-$ $\mathrm{N}_{120} \mathrm{P}_{30} \mathrm{~K}_{60} Z_{25} \mathrm{~S}_{20}, \mathrm{~T}_{5}-\mathrm{N}_{120} \mathrm{P}_{0} \mathrm{~K}_{60} \mathrm{Zn}_{25} \mathrm{~S}_{20}, \quad \mathrm{~T}_{6}-\mathrm{N}_{120} \mathrm{P}_{60} \mathrm{~K}_{30} \mathrm{Zn}_{25} \mathrm{~S}_{20}, \quad \mathrm{~T}_{7} \quad \mathrm{~N}_{120} \mathrm{P}_{60} \mathrm{~K}_{0} Z_{25} \mathrm{~S}_{20}, \quad \mathrm{~T}_{8-}$ $\mathrm{N}_{120} \mathrm{P}_{60} \mathrm{~K}_{60} \mathrm{Zn}_{12.5} \mathrm{~S}_{20}, \mathrm{~T}_{9}-\mathrm{N}_{120} \mathrm{P}_{60} \mathrm{~K}_{60} \mathrm{Zn}_{0} \mathrm{~S}_{20}, \mathrm{~T}_{10}-\mathrm{N}_{120} \mathrm{P}_{60} \mathrm{~K}_{60} \mathrm{Zn}_{25} \mathrm{~S}_{10}, \mathrm{~T}_{11}-\mathrm{N}_{120} \mathrm{P}_{60} \mathrm{~K}_{60} \mathrm{Zn}_{25} \mathrm{~S}_{0}$, and $\mathrm{T}_{12}$ - Control. The high yielding varieties (HYV) rice during Kharif season was MTU 7029 (Swarna) and hybrid variety used in Boro season was Arize 6444 GOLD. The study concludes that application of $\mathrm{N}_{80} \mathrm{P}_{40} \mathrm{~K}_{40} \mathrm{Zn}_{25} \mathrm{~S}_{20}$ ( $\left.\mathrm{T}_{1}\right)$ during kharif and $\mathrm{N}_{120} \mathrm{P}_{60} \mathrm{~K}_{60} \mathrm{Zn}_{25} \mathrm{~S}_{20}\left(\mathrm{~T}_{1}\right)$ in boro season during the two season of experimentation was essential for improving growth attributes, yield components and productivity of high yielding variety (HYV) and hybrid rice. The treatments positively influenced the crop efficiency factors, improved physico-chemical properties and fertility status of the soil and paid highest gross and net returns from the rice cultivation. The study suggests the application of ample dose of fertilizer for better growth, higher productivity, profit and sustainability of rice in the lateritic soil of west Bengal.
\end{abstract}

Keywords: Ample dose, grain yield, rice, nutrient management

\section{Introduction}

Rice is a main staple in more than 100 countries worldwide. Rice is most closely associated with South, Southeast, and East Asia, where $90 \%$ of the world's rice is produced. Asia's hot and humid climate during the long and heavy monsoon season, and the fertile land along the river basins of the major deltas that are regularly flooded, provide the most favourable agroecological environment for rice cultivation. Amongst the rice growing countries, rice cultivation is the most important agricultural operation in India, not only in term of food security but also in term of livelihood. It plays a major part in the diet, economy, employment, culture and history of India. Ninety percent of rice produced is consumed within the country. India ranks number one globally in paddy area with 42.75 million hectares and with production of 105.24 million tonnes (Annonymous, 2014) ${ }^{[1]}$ stands next only to China. While there has been no net increase in the area of rice cultivation in the last 30 years, rice contributes nearly 15 percent of India's annual gross domestic product (GDP) and provides 31 percent of the total calorie supply. India needs to produce 120 million tonnes by 2030 to feed its one and a half billion plus population by then. A real-time analysis of this scenario provides sufficient justification for strengthening, intensifying and introducing cutting edge science and technology for increasing rice productivity in India. In West Bengal, the area and production under food grains during 2012-13 were 5.44 million hectares and 15.02 million tonnes respectively (Gupta et al., 2012 and Das et al.,2014) ${ }^{[7,5]}$. Rice grows in the state in 3 different seasons viz., Aus (autumn rice), Aman (winter rice) and Boro (summer rice). There are three seasons for growing rice in West Bengal viz. - autumn, winter and summer. These three seasons are named according to the season of harvest of the crop. 
Autumn or pre-kharif rice is known as Aus in West Bengal. The pre-monsoon Aus, covers April to July in the northern region and May to September in the southern region of the state and accounts for only $5 \%$ of total rice area and with the expansion of irrigation facilities, the area under this crop has gradually been declining. At present, more than $99 \%$ of the total area is covered with high yielding varieties during $A u s$ season. The winter or monsoon rice, known as Aman, is grown from June to December. It accounted for $69 \%$ of the total rice area and is grown under rainfed conditions in the semi-deep, deep and flooded land (mostly indigenous improved and traditional varieties) and under irrigated conditions in the flood-free medium and shallow lowlands (mostly modern high yielding varieties). Mainly during Aman, farmers still grow some traditional or local ice varieties having special features and it covers nearly about $12 \%$ of the total rice area cultivated during Aman. The remaining 26\% of the rice area is covered by the summer or dry season rice popularly known as Boro. The nutrient mining issues concern the nutrients that are less mobile in soils and have higher potential of staying in the soil. For example, nitrogen $(\mathrm{N})$ is highly mobile in the soil and has the highest probability, among the major nutrients, to be lost from the soil system through volatilization and leaching, among others. The Indian soils, being in the sub-tropical region coupled with the preponderance of tillage practices, are rarely sufficient in $\mathrm{N}$. Nitrogen is generally applied in adequate quantities to the crops, and "nitrogen mining" is not frequently discussed as crop production relies more on adequate external application through fertilizer/manure sources rather than on the native soil reserve of $\mathrm{N}$. The input-output balance calculations for $\mathrm{N}$, at the regional or the national scale, generally show positive balance in soils (Sanyal, 2014) ${ }^{[13]}$. The total fertilizer N needed by rice to achieve a profitable yield target is determined from the anticipated crop response to applied fertilizer $\mathrm{N}$ and a targeted efficiency of fertilizer $\mathrm{N}$ use. Fertilizer $\mathrm{N}$ is supplied at critical growth stages, especially active tillering and panicle initiation, to match the crop needs for supplemental $\mathrm{N}$. Fertilizer $\mathrm{P}$ and $\mathrm{K}$ are applied in sufficient amounts to overcome deficiencies and sustain soil fertility. (Buresh, 2009) [3] Nitrogen management requires special attention in its use so that the large losses can be minimized and the efficiency maximized. Site-specific nutrient management (SSNM) (Banayo et al., 2018) ${ }^{[2]}$ has been found especially useful to achieve the goals of improved productivity and higher $\mathrm{N}$ use efficiency (NUE) (Kumar et al., 2018) ${ }^{[8]}$.

\section{Materials and Methods}

The experiment was conducted during 2014-2015 and 20152016 at farmers' field situated at Binuria village $\left(23^{\circ} 40^{\prime} \mathrm{N}\right.$ and $87^{\circ} 37^{\prime} \mathrm{E}$ ) of Birbhum district of West Bengal under the red and lateritic belt of West Bengal.The experiment was laid out in Randomized Block Design with three replication and twelve treatments in both during kharif and boro season. The plot size was $5 \mathrm{~m} \mathrm{x} 4 \mathrm{~m}$ and the treatment combinations are $\mathrm{T}_{1}-\mathrm{N}_{80} \mathrm{P}_{40} \mathrm{~K}_{40} \mathrm{Zn}_{25} \mathrm{~S}_{20}, \quad \mathrm{~T}_{2}-\mathrm{N}_{40} \mathrm{P}_{40} \mathrm{~K}_{40} \mathrm{Zn}_{25} \mathrm{~S}_{20}, \quad \mathrm{~T}_{3-}$ $\mathrm{N}_{0} \mathrm{P}_{40} \mathrm{~K}_{40} \mathrm{Zn}_{25} \mathrm{~S}_{20}, \quad \mathrm{~T}_{4}-\mathrm{N}_{80} \mathrm{P}_{20} \mathrm{~K}_{40} \mathrm{Zn}_{25} \mathrm{~S}_{20}, \quad \mathrm{~T}_{5}-\mathrm{N}_{80} \mathrm{P}_{0} \mathrm{~K}_{40} \mathrm{Zn}_{25} \mathrm{~S}_{20}$, $\mathrm{T}_{6}-\mathrm{N}_{80} \mathrm{P}_{40} \mathrm{~K}_{20} \mathrm{Zn}_{25} \mathrm{~S}_{20}, \quad \mathrm{~T}_{7}-\mathrm{N}_{80} \mathrm{P}_{40} \mathrm{~K}_{0} \mathrm{Zn}_{25} \mathrm{~S}_{20}, \quad \mathrm{~T}_{8^{-}}$ $\mathrm{N}_{80} \mathrm{P}_{40} \mathrm{~K}_{40} \mathrm{Zn}_{12.5} \mathrm{~S}_{20}, \quad \mathrm{~T}_{9}-\mathrm{N}_{80} \mathrm{P}_{40} \mathrm{~K}_{40} \mathrm{Zn}_{0} \mathrm{~S}_{20}, \quad \mathrm{~T}_{10^{-}}$ $\mathrm{N}_{80} \mathrm{P}_{40} \mathrm{~K}_{40} \mathrm{Zn}_{25} \mathrm{~S}_{10}, \quad \mathrm{~T}-{ }_{11}, \mathrm{~N}_{80} \mathrm{P}_{40} \mathrm{~K}_{40} \mathrm{Zn}_{25} \mathrm{~S}_{0}$ and $\mathrm{T}_{12}$-Control where as in boro season the treatment combinations are $\mathrm{T}_{1-}$ $\mathrm{N}_{120} \mathrm{P}_{60} \mathrm{~K}_{60} \mathrm{Zn}_{25} \mathrm{~S}_{20}, \quad \mathrm{~T}_{2}-\mathrm{N}_{60} \mathrm{~K}_{60} \mathrm{Zn}_{25} \mathrm{~S}_{20}, \quad \mathrm{~T}_{3}-\mathrm{N}_{0} \mathrm{~K}_{60} \mathrm{Zn}_{25} \mathrm{~S}_{20}, \mathrm{~T}_{4-}$ $\mathrm{N}_{120} \mathrm{P}_{30} \mathrm{~K}_{60} \mathrm{Zn}_{25} \mathrm{~S}_{20}, \mathrm{~T}_{5}-\mathrm{N}_{120} \mathrm{P}_{0} \mathrm{~K}_{60} \mathrm{Zn}_{25} \mathrm{~S}_{20}, \mathrm{~T}_{6}-\mathrm{N}_{120} \mathrm{P}_{60} \mathrm{~K}_{30} \mathrm{Zn}_{25} \mathrm{~S}_{20}$, $\mathrm{T}_{7} \quad \mathrm{~N}_{120} \mathrm{P}_{60} \mathrm{~K}_{0} \mathrm{Zn}_{25} \mathrm{~S}_{20}, \quad \mathrm{~T}_{8}-\mathrm{N}_{120} \mathrm{P}_{60} \mathrm{~K}_{60} \mathrm{Zn}_{12.5} \mathrm{~S}_{20}, \mathrm{~T}_{9-}$
$\mathrm{N}_{120} \mathrm{P}_{60} \mathrm{~K}_{60} \mathrm{Zn}_{0} \mathrm{~S}_{20}, \mathrm{~T}_{10}-\mathrm{N}_{120} \mathrm{P}_{60} \mathrm{~K}_{60} \mathrm{Zn}_{25} \mathrm{~S}_{10}, \mathrm{~T}_{11^{-}}$

$\mathrm{N}_{120} \mathrm{P}_{60} \mathrm{~K}_{60} \mathrm{Zn}_{25} \mathrm{~S}_{0}$, and $\mathrm{T}_{12^{-}}$Control. The ample dose of nutrients was 80:40:40:25:20 and 120:60:60:25:20 kg/ha of $\mathrm{N}: \mathrm{P}_{2} \mathrm{O}_{5}: \mathrm{K}_{2} \mathrm{O}: . \mathrm{Zn}: \mathrm{S}$ in kharif and Boro season rice respectively. The high yielding varieties (HYV) rice during Kharif season was MTU 7029 (Swarna). The Hybrid variety used in Boro season was Arize 6444 GOLD. The data were statistically analyzed applying the techniques of analysis of variance and the significance of different sources of variations were tested by error mean square of Fisher Snedecor's 'F' test at probability level 0.05 (Cochran and Cox, 1977) ${ }^{[4]}$.

\section{Results and Discussion \\ Growth Attributes}

The plant height of kharif season rice record highest with application ample dose of nutrients (i.e. $\mathrm{T}_{1}: \mathrm{N}_{80} \mathrm{P}_{40} \mathrm{~K}_{40} \mathrm{Zn}_{25} \mathrm{~S}_{20}$ ) caused significant increase in height of the rice plants over control (i.e. $\mathrm{T}_{12}$ : No fertilizer) in the pooled data analysis. The treatment $\mathrm{T}_{1}\left(\mathrm{~N}_{80} \mathrm{P}_{40} \mathrm{~K}_{40} \mathrm{Zn}_{25} \mathrm{~S}_{20}\right)$ was significantly superior to control and all the treatments produced and statistically at par with $\mathrm{T}_{2}\left(\mathrm{~N}_{40} \mathrm{P}_{40} \mathrm{~K}_{40} \mathrm{Zn}_{25} \mathrm{~S}_{20}\right), \quad \mathrm{T}_{4} \quad\left(\mathrm{~N}_{80} \mathrm{P}_{20} \mathrm{~K}_{40} \mathrm{Zn}_{25} \mathrm{~S}_{20}\right), \quad \mathrm{T}_{5}$ $\left(\mathrm{N}_{80} \mathrm{P}_{0} \mathrm{~K}_{20} \mathrm{Zn}_{25} \mathrm{~S}_{20}\right), \quad \mathrm{T}_{6} \quad\left(\mathrm{~N}_{80} \mathrm{P}_{40} \mathrm{~K}_{20} \mathrm{Zn}_{25} \mathrm{~S}_{20}\right)$, $\mathrm{T}_{8}\left(\mathrm{~N}_{80} \mathrm{P}_{40} \mathrm{~K}_{40} \mathrm{Zn}_{12.5} \mathrm{~S}_{20}\right)$ and $\mathrm{T}_{10}\left(\mathrm{~N}_{80} \mathrm{P}_{40} \mathrm{~K}_{40} \mathrm{Zn}_{25} \mathrm{~S}_{10}\right)$. The plant height of boro season rice also produce similar type of observations as recorded in kharif season rice. $\mathrm{T}_{1}$ remained statistically at par with all other treatment except the treatments $T_{3}$ and control $\left(T_{12}\right)$ remained statistically at par in enhancement of the plant height at the same stage. The dry matter accumulation of kharif and boro rice which was reflected on pooled data of two years of experiment and observed similar trend was noted in dry matter where $T_{1}$ produced significantly higher dry matter than $\mathrm{T}_{3}$ and control. Moreover, $\mathrm{T}_{1}$ remained statistically at par with other treatments except $T_{3}$, and $T_{12}$. The control treatment shows lowest dry matter during the growth stage among all other the treatment (Shankar et al., 2014) ${ }^{[16] .}$

The number of tillers per $\mathrm{m}^{2}$ recorded at harvesting were statistically analyzed and presented in Table 1 and 2 . The data reflect that most of the treatments recorded higher number of tillers per $\mathrm{m}^{2}$ during the two years of experimentation. The resulting showed that the rapid increase in number of tillers was observed during both the years of the experiment wher application of $100 \%$ of recommended dose of fertilizers $\left(\mathrm{T}_{1}: \mathrm{N}_{80} \mathrm{P}_{40} \mathrm{~K}_{40} \mathrm{Zn}_{25} \mathrm{~S}_{20}\right)$ gave maximum number of tiller per $\mathrm{m}^{2}$ was recorded which was statistically at par with the treatments having $\mathrm{T}_{2}-\mathrm{N}_{40} \mathrm{P}_{40} \mathrm{~K}_{40} \mathrm{Zn}_{25} \mathrm{~S}_{20}, \mathrm{~T}_{4}-\mathrm{N}_{80} \mathrm{P}_{20} \mathrm{~K}_{40} \mathrm{Zn}_{25} \mathrm{~S}_{20}$, $\mathrm{T}_{6}-\mathrm{N}_{80} \mathrm{P}_{40} \mathrm{~K}_{20} \mathrm{Zn}_{25} \mathrm{~S}_{20}$ and $\mathrm{T}_{8}-\mathrm{N}_{80} \mathrm{P}_{40} \mathrm{~K}_{40} \mathrm{Zn}_{12.5} \mathrm{~S}_{20}$ in kharif season but during boro rice the pooled data analysis, also produce similar trend and the effect of nutrient management observed that $\mathrm{T}_{1} ; \mathrm{N}_{120} \mathrm{P}_{60} \mathrm{~K}_{60} \mathrm{Zn}_{25} \mathrm{~S}_{20}$ gave higher tillers per plant over $\mathrm{T}_{12}$ (control). $\mathrm{T}_{1}\left(\mathrm{~N}_{120} \mathrm{P}_{60} \mathrm{~K}_{60} \mathrm{Zn}_{25} \mathrm{~S}_{20}\right)$ was significantly superior over $\mathrm{T}_{3}\left(\mathrm{~N}_{0} \mathrm{P}_{60} \mathrm{~K}_{60} \mathrm{Zn}_{25} \mathrm{~S}_{20}\right)$, $\mathrm{T}_{5}\left(\mathrm{~N}_{120} \mathrm{P}_{0} \mathrm{~K}_{60} \mathrm{Zn}_{25} \mathrm{~S}_{20}\right), \quad \mathrm{T}_{7}\left(\mathrm{~N}_{120} \mathrm{P}_{60} \mathrm{~K}_{0} \mathrm{Zn}_{25} \mathrm{~S}_{20}\right)$, $\mathrm{T}_{9}\left(\mathrm{~N}_{120} \mathrm{P}_{60} \mathrm{~K}_{60} \mathrm{Zn}_{0} \mathrm{~S}_{20}\right), \mathrm{T}_{11}\left(\mathrm{~N}_{120} \mathrm{P}_{60} \mathrm{~K}_{60} \mathrm{Zn}_{25} \mathrm{~S}_{0}\right)$ and control $\left(\mathrm{T}_{12}\right)$ which was statistically at par with $\mathrm{T}_{2}-\mathrm{N}_{60} \mathrm{P}_{60} \mathrm{~K}_{60} \mathrm{Zn}_{25} \mathrm{~S}_{20}, \mathrm{~T}_{4-}$ $\mathrm{N}_{120} \mathrm{P}_{30} \mathrm{~K}_{60} \mathrm{Zn}_{25} \mathrm{~S}_{20}, \quad \mathrm{~T}_{6}-\mathrm{N}_{120} \mathrm{P}_{60} \mathrm{~K}_{30} \mathrm{Zn}_{25} \mathrm{~S}_{20}, \quad \mathrm{~T}_{8^{-}}$ $\mathrm{N}_{120} \mathrm{P}_{60} \mathrm{~K}_{60} \mathrm{Zn}_{12.5} \mathrm{~S}_{20}$ and $\mathrm{T}_{10}-\mathrm{N}_{120} \mathrm{P}_{60} \mathrm{~K}_{60} \mathrm{Zn}_{25} \mathrm{~S}_{10}$. The lowest number of tillers per $\mathrm{m}^{2}$ was recorded in $\mathrm{T}_{3}, \mathrm{~T}_{5}, \mathrm{~T}_{7}, \mathrm{~T}_{9}, \mathrm{~T}_{11}$ and control which was due to omission of different nutrients gave less growth attribute compared to ample dose of nutrients which follow similar trend in pooled data analysis during both years of experimentation (Nanjappa et al., 2013) [10]. 


\section{Yield Attributes}

During kharif and boro season of 2014-15 and 2015-16.The yield attributes like number of panicles $\mathrm{m}^{-2}$, panicle length, number of spikelets panicle ${ }^{-1}$ and number of filled grains panicle $^{-1}$ recorded at maturity were presented in the Table $1 \&$ 2. The effect of higher doses of nitrogen, phosphorus, potassium, zinc and sulphur revealed that number of panicles $\mathrm{m}^{-2}$, increased with the $100 \%$ application to rice pooled data analysis of kharif season. The control show least among all other the treatments. The number of panicles per $\mathrm{m}^{-2}$ was maximum in the treatment $\mathrm{T}_{1}\left(\mathrm{~N}_{80} \mathrm{P}_{40} \mathrm{~K}_{40} \mathrm{Zn}_{25} \mathrm{~S}_{20}\right)$ was applied with ample dose of nutrient compared to omission and control treatment and it was statistically at par with $\left(\mathrm{T}_{2}\right)$ $\mathrm{N}_{40} \mathrm{P}_{40} \mathrm{~K}_{40} \mathrm{Zn}_{25} \mathrm{~S}_{20}, \quad\left(\mathrm{~T}_{4}\right) \quad \mathrm{N}_{80} \mathrm{P}_{20} \mathrm{~K}_{40} \mathrm{Zn}_{25} \mathrm{~S}_{20}, \quad\left(\mathrm{~T}_{6}\right)$ $\mathrm{N}_{80} \mathrm{P}_{40} \mathrm{~K}_{20} \mathrm{Zn}_{25} \mathrm{~S}_{20}, \quad\left(\mathrm{~T}_{8}\right) \mathrm{N}_{80} \mathrm{P}_{40} \mathrm{~K}_{40} \mathrm{Zn}_{12.5} \mathrm{~S}_{20}$ and $\left(\mathrm{T}_{10}\right)$ $\mathrm{N}_{80} \mathrm{P}_{40} \mathrm{~K}_{40} \mathrm{Zn}_{25} \mathrm{~S}_{10}$ and Similar trend was recorded in pooled data of boro rice which was statistically at par with $\mathrm{T}_{2}: \mathrm{N}_{60} \mathrm{P}_{60} \mathrm{~K}_{60} \mathrm{Zn}_{25} \mathrm{~S}_{20}$, $\mathrm{T}_{6}: \mathrm{N}_{120} \mathrm{P}_{60} \mathrm{~K}_{30} \mathrm{Zn}_{25} \mathrm{~S}_{20}$, $\mathrm{T}_{4}: \mathrm{N}_{120} \mathrm{P}_{30} \mathrm{~K}_{60} \mathrm{Zn}_{25} \mathrm{~S}_{20}$ $\mathrm{T}_{10}: \mathrm{N}_{120} \mathrm{P}_{60} \mathrm{~K}_{60} \mathrm{Zn}_{25} \mathrm{~S}_{10}$. Among all other the treatment $\mathrm{T}_{1}\left(\mathrm{~N}_{120} \mathrm{P}_{60} \mathrm{~K}_{60} \mathrm{Zn}_{25} \mathrm{~S}_{20}\right)$ show superior and the lowest value shows in control (Shankar et al., 2018) ${ }^{[14,15]}$. The number of filled grain per panicle has been significantly affected due to application of recommended dose of fertilization. The maximum number of grains per panicle has been recorded where $\mathrm{T}_{1} \quad\left(\mathrm{~N}_{80} \mathrm{P}_{40} \mathrm{~K}_{40} \mathrm{Zn}_{25} \mathrm{~S}_{20}\right)$ of recommended dose of fertilizer was applied which was at par with $\left(\mathrm{T}_{2}\right) \mathrm{N}_{40} \mathrm{P}_{40} \mathrm{~K}_{40} \mathrm{Zn}_{25} \mathrm{~S}_{20},\left(\mathrm{~T}_{4}\right) \mathrm{N}_{80} \mathrm{P}_{20} \mathrm{~K}_{40} \mathrm{Zn}_{25} \mathrm{~S}_{20},\left(\mathrm{~T}_{6}\right) \mathrm{N}_{80} \mathrm{P}_{40} \mathrm{~K}_{20} \mathrm{Zn}_{25}$ $\mathrm{S}_{20}$ and $\left(\mathrm{T}_{8}\right) \mathrm{N}_{80} \mathrm{P}_{40} \mathrm{~K}_{40} \mathrm{Zn}_{12.5} \mathrm{~S}_{20}$ which was observed in the pooled data of kharif season and similar trend was followed in the boro season rice. The data has shown in significant increase in number of filled grains per panicle due the recommended dose of NPKZn and $\mathrm{S}$ which was applied in $\left(\mathrm{T}_{1}\right.$ $\mathrm{N}_{120} \mathrm{P}_{60} \mathrm{~K}_{60} \mathrm{Zn}_{25} \mathrm{~S}_{20}$ ) and recorded as the highest number of grains per panicle (142.7) which was significantly superior to all the treatments. This was closely followed by $\mathrm{T}_{2-}$ $\mathrm{N}_{60} \mathrm{P}_{60} \mathrm{~K}_{60} \mathrm{Zn}_{25} \mathrm{~S}_{20}, \mathrm{~T}_{4}-\mathrm{N}_{120} \mathrm{P}_{30} \mathrm{~K}_{60} \mathrm{Zn}_{25} \mathrm{~S}_{20}, \mathrm{~T}_{6}-\mathrm{N}_{120} \mathrm{P}_{60} \mathrm{~K}_{30} \mathrm{Zn}_{25} \mathrm{~S}_{20}$ and $\mathrm{T}_{8}-\mathrm{N}_{120} \mathrm{P}_{60} \mathrm{~K}_{60} \mathrm{Zn}_{12.5} \mathrm{~S}_{20}$. the Control $\left(\mathrm{T}_{12}\right)$ treatment was recorded the lowest number of filled grains per panicle among all the treatments.. The number of spikelets per panicle is one of the important yield contributing parameters of rice which ultimately determines the total yield of the crop. In pooled data analysis, the observations on number of spikelets per panicle were recorded and a significant variation among the treatments was noticed. Among the different treatment combinations, the application of $\mathrm{N}_{80} \mathrm{P}_{40} \mathrm{~K}_{40} \mathrm{Zn}_{25} \mathrm{~S}_{20} \quad\left(\mathrm{~T}_{1}\right)$ produced significantly higher number of spikelets per panicle (149.6) than control in the pooled data of kharif rice. The data $\mathrm{T}_{1}$ gave significantly better result which was statistically at par with $\quad \mathrm{T}_{2}: \mathrm{N}_{40} \mathrm{P}_{40} \mathrm{~K}_{40} \mathrm{Zn}_{25} \mathrm{~S}_{20}, \quad \mathrm{~T}_{4}: \mathrm{N}_{80} \mathrm{P}_{20} \mathrm{~K}_{40} \mathrm{Zn}_{25} \mathrm{~S}_{20}$, $\mathrm{T}_{6}: \mathrm{N}_{80} \mathrm{P}_{40} \mathrm{~K}_{20} \mathrm{Zn}_{25} \mathrm{~S}_{20}, \quad \mathrm{~T}_{8}: \mathrm{N}_{80} \mathrm{P}_{40} \mathrm{~K}_{40} \mathrm{Zn}_{12.5} \mathrm{~S}_{20} \quad$ and $\mathrm{T}_{10}: \mathrm{N}_{80} \mathrm{P}_{40} \mathrm{~K}_{40} \mathrm{Zn}_{25} \mathrm{~S}_{10}$. The pooled of boro season rice which was closely follow similar trend. The treatment with $100 \%$ of RDF gave maximum value among all the treatment and the lowest number of spikelets per panicle observed in control (no fertilizer) (Ray et al., 2015 and Shankar et al., 2018) ${ }^{[12,14,15] .}$

\section{Yield $\left(\mathrm{t} \mathrm{ha}^{-1}\right)$}

The Grain and straw yield $\left(\mathrm{t} \mathrm{ha}^{-1}\right)$ observed that the highest grain yield $\left(5.6 \mathrm{t} \mathrm{ha}^{-1}\right)$ and straw yield $\left(7.5 \mathrm{t} \mathrm{ha}^{-1}\right)$ of kharif rice (Table $1 \& 2$ ). in the pooled data which shows that the grain yield has increased significantly due to application of ample dose of nutrient $\mathrm{T}_{1}\left(\mathrm{~N}_{80} \mathrm{P}_{40} \mathrm{~K}_{40} \mathrm{Zn}_{25} \mathrm{~S}_{20}\right)$ with compared to the control and Application of fertilizer to rice-rice based cropping system has resulted significantly and appreciably higher grain yield of rice in both the season. Which was statistically at par with all other treatment except $T_{3}$ and $T_{12}$. The maximum grain and straw yield of rice was recorded in $\mathrm{T}_{1}\left(\mathrm{~N}_{80} \mathrm{P}_{40} \mathrm{~K}_{40} \mathrm{Zn}_{25} \mathrm{~S}_{20}\right)$. The pooled of boro season (2015 \& 2016), the highest grain and straw yield $\left(6.60 \& 8.52 \mathrm{t} \mathrm{ha}^{-1}\right)$ was achieved $\mathrm{T}_{1}\left(\mathrm{~N}_{120} \mathrm{P}_{60} \mathrm{~K}_{60} \mathrm{Zn}_{25} \mathrm{~S}_{20}\right)$ applied with ample dose of nutrients which was statistically at par with $\mathrm{T}_{4}\left(\mathrm{~N}_{120} \mathrm{P}_{30} \mathrm{~K}_{60} \mathrm{Zn}_{25} \mathrm{~S}_{20}\right), \mathrm{T}_{5}\left(\mathrm{~N}_{120} \mathrm{P}_{0} \mathrm{~K}_{60} \mathrm{Zn}_{25} \mathrm{~S}_{20}\right), \mathrm{T}_{6}\left(\mathrm{~N}_{120} \mathrm{P}_{60} \mathrm{~K}_{30} \mathrm{Zn}_{2}\right.$ $\left.{ }_{5} \mathrm{~S}_{20}\right), \quad \mathrm{T}_{7}\left(\mathrm{~N}_{120} \mathrm{P}_{60} \mathrm{~K}_{0} \mathrm{Zn}_{25} \mathrm{~S}_{20}\right), \quad \mathrm{T}_{8}\left(\mathrm{~N}_{120} \mathrm{P}_{60} \mathrm{~K}_{60} Z_{n_{12.5}} \mathrm{~S}_{20}\right)$, $\mathrm{T}_{9}\left(\mathrm{~N}_{120} \mathrm{P}_{60} \mathrm{~K}_{60} \mathrm{Zn}_{0} \mathrm{~S}_{20}\right), \quad \mathrm{T}_{10}\left(\mathrm{~N}_{120} \mathrm{P}_{60} \mathrm{~K}_{60} \mathrm{Zn}_{25} \mathrm{~S}_{10}\right) \quad$ and $\mathrm{T}_{11}\left(\mathrm{~N}_{120} \mathrm{P}_{60} \mathrm{~K}_{60} \mathrm{Zn}_{25} \mathrm{~S}_{0}\right)$ with compared to control treatment. The treatment combination with $100 \%$ recommended dose of fertilizers has brought about significant improvement in yield of kharif and boro rice over control treatments. The ample dose of nutrients $\left(\mathrm{T}_{1}\right)$ has proved appreciably and significantly superior to all other the treatments (Kumar et al. 2018) ${ }^{[8]}$. Which resulted the maximum yield of rice-rice cropping system and the lowest straw yield has been recorded in the control plot in both years of the experiment (Shankar et al., 2014) ${ }^{[16]}$.

Table 1: Effect of nutrient management on growth and yield attributes of Kharif rice (pooled data over two years)

\begin{tabular}{|c|c|c|c|c|c|c|c|c|}
\hline Treatment & \begin{tabular}{|c|}
$\begin{array}{c}\text { Plant height } \\
(\mathrm{cm})\end{array}$ \\
\end{tabular} & \begin{tabular}{|c|} 
Dry matter \\
Accumulation (g) \\
\end{tabular} & \begin{tabular}{|c|} 
Tiller \\
$\mathbf{m}^{-2}$ \\
\end{tabular} & $\begin{array}{l}\text { Number of } \\
\text { panicles/m² }\end{array}$ & \begin{tabular}{|c|}
$\begin{array}{c}\text { Number of filled } \\
\text { grains/panicle }\end{array}$ \\
\end{tabular} & \begin{tabular}{|c|} 
Number of \\
Spikelets/panicle
\end{tabular} & \begin{tabular}{|c|}
$\begin{array}{c}\text { Grain yield } \\
\left(\mathrm{t} \mathrm{ha}^{-1}\right)\end{array}$ \\
\end{tabular} & $\begin{array}{c}\text { Straw yield } \\
\left(\mathbf{t ~ h a}^{-1}\right)\end{array}$ \\
\hline $\mathrm{T}_{1}\left(\mathrm{~N}_{120} \mathrm{P}_{60} \mathrm{~K}_{60} \mathrm{Zn}_{25} \mathrm{~S}_{20}\right)$ & 119.6 & 1308.3 & 312.1 & 248 & 132.1 & 149.6 & 5.56 & 7.59 \\
\hline $\mathrm{T}_{2}\left(\mathrm{~N}_{60} \mathrm{P}_{60} \mathrm{~K}_{60} \mathrm{Zn}_{25} \mathrm{~S}_{20}\right)$ & 111.1 & 1252.7 & 296.9 & 243 & 127.6 & 146.4 & 4.82 & 7.1 \\
\hline $\mathrm{T}_{3}\left(\mathrm{~N}_{0} \mathrm{P}_{60} \mathrm{~K}_{60} \mathrm{Zn}_{25} \mathrm{~S}_{20}\right)$ & 95.4 & 661.7 & 258.4 & 209.9 & 110.3 & 132.5 & 3.32 & 5.18 \\
\hline $\mathrm{T}_{4}\left(\mathrm{~N}_{120} \mathrm{P}_{30} \mathrm{~K}_{60} \mathrm{Zn}_{25} \mathrm{~S}_{20}\right)$ & 117 & 1242.6 & 295.9 & 245.4 & 122.3 & 145.5 & 5.26 & 7.45 \\
\hline $\mathrm{T}_{5}\left(\mathrm{~N}_{120} \mathrm{P}_{0} \mathrm{~K}_{60} \mathrm{Zn}_{25} \mathrm{~S}_{20}\right)$ & 108.5 & 1213.2 & 277.2 & 239.3 & 113.1 & 135.8 & 5.03 & 7.35 \\
\hline $\mathrm{T}_{6}\left(\mathrm{~N}_{120} \mathrm{P}_{60} \mathrm{~K}_{30} \mathrm{Zn}_{25} \mathrm{~S}_{20}\right)$ & 115.1 & 1233.2 & 303.3 & 234.6 & 126.9 & 149.2 & 5.18 & 7.46 \\
\hline $\mathrm{T}_{7}\left(\mathrm{~N}_{120} \mathrm{P}_{60} \mathrm{~K}_{0} \mathrm{Zn}_{25} \mathrm{~S}_{20}\right)$ & 103.6 & 1209.4 & 274.5 & 226.3 & 112.4 & 136.3 & 5.07 & 7.29 \\
\hline $\mathrm{T}_{8}\left(\mathrm{~N}_{120} \mathrm{P}_{60} \mathrm{~K}_{60} \mathrm{Zn}_{12.5} \mathrm{~S}_{20}\right)$ & 114.2 & 1237.7 & 302.7 & 246 & 124.9 & 148 & 5.21 & 7.52 \\
\hline $\mathrm{T}_{9}\left(\mathrm{~N}_{120} \mathrm{P}_{60} \mathrm{~K}_{60} \mathrm{Zn}_{0} \mathrm{~S}_{20}\right)$ & 100.8 & 1206.4 & 274.4 & 217.2 & 113.6 & 135.6 & 5.02 & 7.47 \\
\hline $\mathrm{T}_{10}\left(\mathrm{~N}_{120} \mathrm{P}_{60} \mathrm{~K}_{60} \mathrm{Zn}_{25} \mathrm{~S}_{10}\right)$ & 114.2 & 1222.8 & 299.2 & 245 & 118.2 & 145.5 & 5.32 & 7.53 \\
\hline $\mathrm{T}_{11}\left(\mathrm{~N}_{120} \mathrm{P}_{60} \mathrm{~K}_{60} \mathrm{Zn}_{25} \mathrm{~S}_{0}\right)$ & 96 & 1244 & 273.2 & 220.4 & 113 & 133.8 & 5.28 & 7.50 \\
\hline $\mathrm{T}_{12}(\mathrm{Control})$ & 88.1 & 516.3 & 198.8 & 188.1 & 63.6 & 108.4 & 2.31 & 4.08 \\
\hline $\operatorname{SEm}( \pm)$ & 6.5 & 64.6 & 9.6 & 7.2 & 5.9 & 4 & 0.25 & 0.33 \\
\hline $\mathrm{CD}(p=0.05)$ & 19 & 189.3 & 28.2 & 21.2 & 17.2 & 11.7 & 0.74 & 0.98 \\
\hline $\mathrm{CV}(\%)$ & 10.4 & 11.1 & 6 & 5.3 & 8.8 & 4.8 & 9.15 & 8.3 \\
\hline
\end{tabular}


Table 2: Effect of nutrient management on growth and yield attributes of Boro rice (pooled data over two years)

\begin{tabular}{|c|c|c|c|c|c|c|c|c|}
\hline Treatment & \begin{tabular}{|c|} 
Plant \\
height $(\mathbf{c m})$
\end{tabular} & $\begin{array}{c}\text { Dry matter } \\
\text { Accumulation (g) }\end{array}$ & \begin{tabular}{|c|} 
Tiller \\
$\mathbf{m}^{-2}$
\end{tabular} & $\begin{array}{l}\text { Number of } \\
\text { panicles } / \mathbf{m}^{2}\end{array}$ & $\begin{array}{c}\text { Number of filled } \\
\text { grains/panicle }\end{array}$ & $\begin{array}{c}\text { Number of } \\
\text { Spikelets/panicle }\end{array}$ & $\begin{array}{c}\text { Grain yield } \\
\left(\mathrm{t} \mathrm{ha}^{-1}\right)\end{array}$ & $\begin{array}{c}\text { Straw yield } \\
\left(\mathrm{t} \mathrm{ha}^{-1}\right)\end{array}$ \\
\hline $\mathrm{T}_{1}\left(\mathrm{~N}_{120} \mathrm{P}_{60} \mathrm{~K}_{60} \mathrm{Zn}_{25} \mathrm{~S}_{20}\right)$ & 123.2 & 1417.2 & 360.8 & 281.6 & 142.7 & 157.3 & 6.60 & 8.52 \\
\hline $\mathrm{T}_{2}\left(\mathrm{~N}_{60} \mathrm{P}_{60} \mathrm{~K}_{60} \mathrm{Zn}_{25} \mathrm{~S}_{20}\right)$ & 118.0 & 1397.7 & 360.9 & 275.1 & 134.5 & 151.6 & 5.88 & 8.06 \\
\hline $\mathrm{T}_{3}\left(\mathrm{~N}_{0} \mathrm{P}_{60} \mathrm{~K}_{60} \mathrm{Zn}_{25} \mathrm{~S}_{20}\right)$ & 96.4 & 668.4 & 310.6 & 237.2 & 90.8 & 125.6 & 3.44 & 5.96 \\
\hline $\mathrm{T}_{4}\left(\mathrm{~N}_{120} \mathrm{P}_{30} \mathrm{~K}_{60} \mathrm{Zn}_{25} \mathrm{~S}_{20}\right)$ & 117.4 & 1402.9 & 355.1 & 267.3 & 132.5 & 155.5 & 6.18 & 8.39 \\
\hline $\mathrm{T}_{5}\left(\mathrm{~N}_{120} \mathrm{P}_{0} \mathrm{~K}_{60} \mathrm{Zn}_{25} \mathrm{~S}_{20}\right)$ & 114.9 & 1389.5 & 328.3 & 255.2 & 129.6 & 143.7 & 6.06 & 7.91 \\
\hline $\mathrm{T}_{6}\left(\mathrm{~N}_{120} \mathrm{P}_{60} \mathrm{~K}_{30} \mathrm{Zn}_{25} \mathrm{~S}_{20}\right)$ & 119.2 & 1403.3 & 354.9 & 278.5 & 131.1 & 156.5 & 6.22 & 8.45 \\
\hline $\mathrm{T}_{7}\left(\mathrm{~N}_{120} \mathrm{P}_{60} \mathrm{~K}_{0} \mathrm{Zn}_{25} \mathrm{~S}_{20}\right)$ & 112.7 & 1380.6 & 332.4 & 258.1 & 130.6 & 141.0 & 6.12 & 8.30 \\
\hline $\mathrm{T}_{8}\left(\mathrm{~N}_{120} \mathrm{P}_{60} \mathrm{~K}_{60} \mathrm{Zn}_{12.5} \mathrm{~S}_{20}\right)$ & 121.5 & 1401.0 & 351.5 & 279.7 & 135.6 & 151.8 & 6.31 & 8.46 \\
\hline $\mathrm{T}_{9}\left(\mathrm{~N}_{120} \mathrm{P}_{60} \mathrm{~K}_{60} \mathrm{Zn}_{0} \mathrm{~S}_{20}\right)$ & 120.2 & 1383.5 & 342.6 & 263.6 & 131.0 & 146.1 & 6.23 & 8.48 \\
\hline $\mathrm{T}_{10}\left(\mathrm{~N}_{120} \mathrm{P}_{60} \mathrm{~K}_{60} \mathrm{Zn}_{25} \mathrm{~S}_{10}\right)$ & 117.2 & 1405.0 & 351.1 & 267.5 & 138.1 & 153.2 & 6.25 & 8.51 \\
\hline $\mathrm{T}_{11}\left(\mathrm{~N}_{120} \mathrm{P}_{60} \mathrm{~K}_{60} \mathrm{Zn}_{25} \mathrm{~S}_{0}\right)$ & 118.1 & 1399.7 & 337.8 & 263.4 & 131.6 & 140.9 & 6.11 & 8.30 \\
\hline $\mathrm{T}_{12}$ (Control) & 84.4 & 587.0 & 226.5 & 212.6 & 78.0 & 140.5 & 2.06 & 4.78 \\
\hline $\operatorname{SEm}( \pm)$ & 7.7 & 62.2 & 10.2 & 7.6 & 6.8 & 5.9 & 0.25 & 0.39 \\
\hline $\mathrm{CD}(p=0.05)$ & 22.7 & 182.3 & 29.8 & 22.3 & 20.1 & 17.4 & 0.72 & 1.14 \\
\hline $\mathrm{CV}(\%)$ & 12.4 & 9.3 & 5.4 & 5.1 & 9.5 & 6.9 & 7.60 & 8.58 \\
\hline
\end{tabular}

\section{Economics}

The gross return $\left(\mathrm{Rs} \mathrm{ha}^{-1}\right)$ of high yielding rice and hybrid rice grown during kharif (2014 \& 2015) and boro (2015 \& 2016) season with different nutrient management practices was estimated on the basis of prevailing market price of different inputs and outputs. The data on gross return, net return in rice cultivation were analyzed statistically and presented in the Table 3. The pooled data of kharif and boro season rice for the gross return was found that the highest obtained in the ample dose $\left(\mathrm{T}_{1}: \mathrm{N}_{80} \mathrm{P}_{40} \mathrm{~K}_{40} \mathrm{Zn}_{25} \mathrm{~S}_{20}\right)$. The gross return (Rs ha $\left.{ }^{-1}\right)$ was significantly affected by nutrient application of ample dose of NPKZnS applied plot was significantly superior than the control plot. The application of $100 \% \mathrm{~N}+\mathrm{P}+\mathrm{K}+\mathrm{Zn}+\mathrm{S}$ dose increased yield components, which ultimately reflected on grain yield and straw yield. Due increased in yield which cause the higher gross return in $\mathrm{T}_{1}$ and highest among all the treatment which was statistically at par with $\mathrm{T}_{10}$ (Singh et al., 2015 and Yadav 2018). The pooled of net return followed similar trend to that of gross return during both the season. The highest net return was recorded from the crop having $\mathrm{T}_{1}$ in kharif and boro rice resectivily (Rs. 57408.3 and $67,491.4 \mathrm{ha}^{-1}$ ) and was significantly higher than that of all other fertility treatments. The crop has no fertilizers applied paid the lowest net return which was significantly lower than all other fertility treatments. Due to high requirement of fertilizers and its high cost which directly enhanced in higher grain and straw yield and which reflected in net return of ricerice cropping system. The highest benefit cost ratio was realized under the application of $\mathrm{N}_{80} \mathrm{P}_{40} \mathrm{~K}_{40} \mathrm{Zn}_{25} \mathrm{~S}_{20}\left(\mathrm{~T}_{1}\right)$ the average $\mathrm{B}: \mathrm{C}$ ratio invested was maximum (1.61) and was followed by $\mathrm{T}_{4}-\mathrm{N}_{80} \mathrm{P}_{20} \mathrm{~K}_{40} \mathrm{Zn}_{25} \mathrm{~S}_{20}, \mathrm{~T}_{5}-\mathrm{N}_{80} \mathrm{P}_{0} \mathrm{~K}_{40} \mathrm{Zn}_{25} \mathrm{~S}_{20}, \mathrm{~T}_{10^{-}}$ $\mathrm{N}_{80} \mathrm{P}_{40} \mathrm{~K}_{40} \mathrm{Zn}_{25} \mathrm{~S}_{10}$ and $\mathrm{T}_{11}-\mathrm{N}_{80} \mathrm{P}_{40} \mathrm{~K}_{40} \mathrm{Zn}_{25} \mathrm{~S}_{0}$. Among all the nutrient management practices the lowest value was recorded in control (0.29). The lowest gross return, net return and B:C ratio were received from these treatments due to poor growth of the crop, no application of fertilizers which led to produce lower grain and straw yield. Among the chemical treatments $\mathrm{T}_{1}$ recorded higher grain and straw yield economically it was superior to all the treatments. The crop received $\mathrm{N}_{120} \mathrm{P}_{0} \mathrm{~K}_{60} \mathrm{Zn}_{25} \mathrm{~S}_{20}\left(\mathrm{~T}_{1}\right)$ paid the highest benefit cost ratio (1.62) and statistically at par with $\mathrm{T}_{4}: \mathrm{N}_{120} \mathrm{P}_{30} \mathrm{~K}_{60} \mathrm{Zn}_{25} \mathrm{~S}_{20}$ and $\mathrm{T}_{5}$ $: \mathrm{N}_{120} \mathrm{P}_{0} \mathrm{~K}_{60} \mathrm{Zn}_{25} \mathrm{~S}_{20}$. The study indicates the need of ample dose of nutrition of hybrid rice for greater productivity along with higher profit. Whereas control (0.06) respond lesser compared to other treatments (Das et al., $2010^{[6]}$ and Mauriya et al., 2013) ${ }^{[9]}$.

\section{Agronomic efficiency (AE)}

The NPKZnS level registered significant effect on agronomic efficiency (AE) during kharif and boro season. There was a strong negative relationship between agronomic efficiency (AE) and nutrient level. The decreased markedly as the NPKZnS level increased. Agronomic efficiency, which reflects the production per $\mathrm{kg}$ of nutrient applied, has varied appreciably due to different treatments and similar effect was observed in the pooled data analysis (Table 3). The fertilizer with $50 \%$ recommended dose of fertilizer was applied to kharif and boro rice has recorded higher agronomy efficiency than that of $100 \%$ recommended dose of fertilizer $\left(\mathrm{T}_{1}\right)$. Waiving the fertilizers application as of $\mathrm{T}_{2}, \mathrm{~T}_{4}, \mathrm{~T}_{6}, \mathrm{~T}_{8}$ and $\mathrm{T}_{10}$ produced better effects on agronomic efficiency which has remarkably increased amongst all the treatments which was followed by $100 \%$ recommended fertilizer level (Ravisankar et al., 2014) ${ }^{[11]}$.

Table 3: Effect of nutrient management on economics and Agronomic efficiency (AE) of kharif and Boro rice (pooled data over two years)

\begin{tabular}{|c|c|c|c|c|c|c|c|c|c|}
\hline Treatment & \begin{tabular}{|c|} 
Gross \\
$\begin{array}{c}\text { Return }^{(R s} \\
\left.\text { ha }^{-1}\right)\end{array}$ \\
\end{tabular} & $\begin{array}{c}\text { Net Return } \\
\left(\text { Rs ha }^{-1}\right)\end{array}$ & $\begin{array}{l}\text { B:C } \\
\text { Ratio }\end{array}$ & $\begin{array}{c}\text { Agronomic } \\
\text { efficiency (AE) }\end{array}$ & Treatment & $\begin{array}{c}\text { Gross } \\
\begin{array}{c}\text { Return }(\text { Rs } \\
\left.\text { ha }^{-1}\right)\end{array} \\
\end{array}$ & $\begin{array}{c}\text { Net Return } \\
\left(\text { Rs ha }^{-1}\right)\end{array}$ & B:C & $\begin{array}{c}\text { Agronomic } \\
\text { efficiency (AE) }\end{array}$ \\
\hline $\mathrm{T}_{1}\left(\mathrm{~N}_{80} \mathrm{P}_{40} \mathrm{~K}_{40} \mathrm{Zn}_{25} \mathrm{~S}_{20}\right)$ & 93139.2 & 57408.3 & 1.61 & 40.6 & $\mathrm{~T}_{1}\left(\mathrm{~N}_{120} \mathrm{P}_{60} \mathrm{~K}_{60} \mathrm{Zn}_{25} \mathrm{~S}_{20}\right)$ & 109754.5 & 491.4 & 1.60 & 37.8 \\
\hline $\mathrm{T}_{2}\left(\mathrm{~N}_{40} \mathrm{P}_{40} \mathrm{~K}_{40} \mathrm{Zn}_{25} \mathrm{~S}_{20}\right)$ & 81455.0 & 46332.7 & 1.32 & 62.7 & $\mathrm{~T}_{2}\left(\mathrm{~N}_{60} \mathrm{P}_{60} \mathrm{~K}_{60} \mathrm{Zn}_{25} \mathrm{~S}_{20}\right)$ & 98575.0 & $57,225.0$ & 1.39 & 63.7 \\
\hline $\mathrm{T}_{3}\left(\mathrm{~N}_{0} \mathrm{P}_{40} \mathrm{~K}_{40} \mathrm{Zn}_{25} \mathrm{~S}_{20}\right)$ & 56517.5 & 22003.9 & 0.64 & 0.0 & $\mathrm{~T}_{3}\left(\mathrm{~N}_{0} \mathrm{P}_{60} \mathrm{~K}_{60} \mathrm{Zn}_{25} \mathrm{~S}_{20}\right)$ & 59455.8 & $19,018.7$ & 0.47 & 0.0 \\
\hline $\mathrm{T}_{4}\left(\mathrm{~N}_{80} \mathrm{P}_{20} \mathrm{~K}_{40} \mathrm{Zn}_{25} \mathrm{~S}_{20}\right)$ & 88473.4 & 53631.3 & 1.54 & 36.9 & $\mathrm{~T}_{4}\left(\mathrm{~N}_{120} \mathrm{P}_{30} \mathrm{~K}_{60} \mathrm{Zn}_{25} \mathrm{~S}_{20}\right)$ & 103479.3 & $62,549.6$ & 1.53 & 34.4 \\
\hline $\mathrm{T}_{5}\left(\mathrm{~N}_{80} \mathrm{P}_{0} \mathrm{~K}_{40} \mathrm{Zn}_{25} \mathrm{~S}_{20}\right)$ & 85017.2 & 3.9 & 1.50 & 34.0 & $\mathrm{~T}_{5}\left(\mathrm{~N}_{120} \mathrm{P}_{0} \mathrm{~K}_{60} \mathrm{Zn}_{25} \mathrm{~S}_{20}\right)$ & 100956.6 & 360.1 & 1.55 & 33.4 \\
\hline $\mathrm{T}_{6}\left(\mathrm{~N}_{80} \mathrm{P}_{40} \mathrm{~K}_{20} \mathrm{Zn}_{25} \mathrm{~S}_{20}\right)$ & 87383.2 & 52185.1 & 1.48 & 35.9 & $\mathrm{~T}_{6}\left(\mathrm{~N}_{120} \mathrm{P}_{60} \mathrm{~K}_{30} \mathrm{Zn}_{25} \mathrm{~S}_{20}\right)$ & 104149.9 & $62,686.8$ & 1.51 & 34.7 \\
\hline $\mathrm{T}_{7}\left(\mathrm{~N}_{80} \mathrm{P}_{40} \mathrm{~K}_{0} \mathrm{Zn}_{25} \mathrm{~S}_{20}\right)$ & 85507.0 & 50841.7 & 1.47 & 34.5 & $\mathrm{~T}_{7}\left(\mathrm{~N}_{120} \mathrm{P}_{60} \mathrm{~K}_{0} \mathrm{Zn}_{25} \mathrm{~S}_{20}\right)$ & 102407.2 & $61,744.1$ & 1.52 & 33.8 \\
\hline $\mathrm{T}_{8}\left(\mathrm{~N}_{80} \mathrm{P}_{40} \mathrm{~K}_{40} \mathrm{Zn}_{12.5} \mathrm{~S}_{20}\right)$ & 87841.3 & 52193.6 & 1.46 & 36.2 & $\mathrm{~T}_{8}\left(\mathrm{~N}_{120} \mathrm{P}_{60} \mathrm{~K}_{60} \mathrm{Zn}_{12.5} \mathrm{~S}_{20}\right)$ & 105478.7 & $63,298.8$ & 1.50 & 35.4 \\
\hline $\mathrm{T}_{9}\left(\mathrm{~N}_{80} \mathrm{P}_{40} \mathrm{~K}_{40} \mathrm{Zn}_{0} \mathrm{~S}_{20}\right)$ & 85017.5 & & 1.39 & 33.9 & $\mathrm{~T}_{9}\left(\mathrm{~N}_{120} \mathrm{P}_{60} \mathrm{~K}_{60} \mathrm{Zn}_{0} \mathrm{~S}_{20}\right)$ & 104286.5 & $62,189.8$ & 1.48 & 34.7 \\
\hline $\mathrm{T}_{10}\left(\mathrm{~N}_{80} \mathrm{P}_{40} \mathrm{~K}_{40} \mathrm{Zn}_{25} \mathrm{~S}_{10}\right)$ & 89530.9 & 54022.0 & 1.52 & 37.6 & $\mathrm{~T}_{10}\left(\mathrm{~N}_{120} \mathrm{P}_{60} \mathrm{~K}_{60} \mathrm{Zn}_{25} \mathrm{~S}_{10}\right)$ & 104711.2 & $62,670.1$ & 1.49 & 35.0 \\
\hline
\end{tabular}




\begin{tabular}{|c|c|c|c|c|c|c|c|c|c|}
\hline $\mathrm{T}_{11}\left(\mathrm{~N}_{80} \mathrm{P}_{40} \mathrm{~K}_{40} \mathrm{Zn}_{25} \mathrm{~S}_{00}\right)$ & 88870.7 & 53583.8 & 1.52 & 37.1 & $\mathrm{~T}_{11}\left(\mathrm{~N}_{120} \mathrm{P}_{60} \mathrm{~K}_{60} \mathrm{Zn}_{25} \mathrm{~S}_{0}\right)$ & 102291.6 & $60,472.5$ & 1.45 & 33.8 \\
\hline $\mathrm{T}_{12}(\mathrm{Con} t$ rol $)$ & 40070.4 & 9010.4 & 0.29 & 0.0 & $\mathrm{~T}_{12}(\mathrm{Con}$ trol $)$ & 37430.7 & $1,870.7$ & 0.05 & 0.0 \\
\hline S.Em $( \pm)$ & 1972.6 & 1783.1 & 0.04 & - & $\mathrm{SEm}( \pm)$ & 4923.7 & 2461.8 & 0.05 & - \\
\hline C.D $(p=0.05)$ & 5785.0 & 5229.1 & 0.11 & - & $\mathrm{CD}(p=0.05)$ & 14439.3 & 7219.7 & 0.16 & - \\
\hline C. $(\%)$ & 4.3 & 6.7 & 4.93 & - & $\mathrm{CV}(\%)$ & 9.0 & 7.9 & 7.18 & - \\
\hline
\end{tabular}

\section{Conclusion}

Thus It may concluded that the nutrient management approach enhance the growth, productivity and nutrient use efficiency showed positive and significant relationships which in turn positively influenced by the application of ample dose of nutrients. The application of macro and micro nutrient from chemical fertilizers gave better result compared to omission and control treatments. which produced significantly better growth and productivity under rice-rice cropping system.

\section{References}

1. Annonymous, Directorate of Economics and Statistics, Department of Agriculture \& Cooperation. Obtained by http.eands.dacnet.nic.in/PDF/Agricultural- Statistics-AtGlance, pdf, 2014.

2. Banayo NPMC, Haefele SM, Desamero NV, Kato Y. Onfarm assessment of site-specific nutrient management for rainfed lowland rice in the Philippines. Field Crops Res. 2018; 220:88-96.

3. Buresh Roland. The SSNM concept and its implementation in rice. In: IFA, Cross Roads ASIPacific, Kota Kinabalu, Malaysia held on 2008, 2009, 610.

4. Cochran WG, Cox GM. Experimental Design. Asia Publishing House. Calcutta. 1977, 95-132, 142-181.

5. Das A, Patel DP, Munda GC, Ramkrushna GI, Kumar M, Ngachan SV. Improving productivity, water and energy use efficiency in lowland rice (Oryza sativa) through appropriate establishment methods and nutrient management practices in the mid altitudes of north east India. Expt Agric. 2014; 50(3):353-375

6. Das A, Tomar JMS, Ramesh T, Munda GC, Ghosh PK, Patel DP. Productivity and economics of lowland rice as influenced by $\mathrm{N}$-fixing tree leaves under mid-altitude subtropical Meghalaya. Nutrient Cycling in Agroecosystem. 2010; 87:9-19

7. Gupta SB, Ayam GP. Estimation of indigenous nutrient supply capacity of soil for SSNM in irrigated riceof Chhattisgarh. Indian Journal of Fertilisers. 2012; 8(7):4853.

8. Kumar V, Naresh RK, Kumar S, Kumar S, Kumar A, Gupta RK et al. Efficient Nutrient Management Practices for Sustaining Soil Health and Improving Rice-Wheat Productivity: A Review. Journal of Pharmacognosy and Phytochemistry. 2018; 7(1): 585-597

9. Mauriya AK, Maurya VK, Tripathi HP, Verma RK, Radhey Shyam. Effect of site-specific nutrient management on productivity and economics of rice (Oryza sativa)-wheat (Tritucum aestivum) system. Indian Journal of Agronomy. 2013; 58(3):282-287.

10. Nanjappa AS, Ramachandrappa HV, Hittalmani BK, Shailaja Basavaraj PK. Performance of aerobic rice (Oryza sativa L.) genotypes under site specific nutrient management (SSNM). Research on Crops. 2013; 14(2):350-356.

11. Ravisankar N, Gangwar B, Prasad K. Influence of balanced fertilization on productivity and nutrient use efficiency of cereal based cropping systems. Indian Journal of Agricultural Sciences. 2014; 84(2):248-54
12. Ray SK, Mukhopadhyay D. Balanced use of nutrients for high crop yield and quality of rice in central uttar Pradesh. International Journal of Technical Research and Applications. 2015; 3(4):344-346

13. Sanyal SK. Nutrient mining in soil-an issue of concern. News letter Indian Soc Soil Sci. New Delhi. 2014; 36:13.

14. Shankar T, Malik GC, Banerjee M. Effect of nutrient management on yield attributes and yields in rice based cropping system. International journal of bio-resource, environment and agricultural sciences (ijbeas.) 2018; 4(2):704-708

15. Shankar T, Malik GC, Banerjee M. Nutrient management in rice-rice based cropping system on growth and productivity of lateritic soil of West Bengal. International journal of bio-resource, environment and agricultural sciences (ijbeas). 2018; 4(1):681-686, 2018

16. Shankar T, Malik GC, Banerjee M, Ghosh A. Nutrient optimization on growth and productivity of rice in the red and lateritic belt of West Bengal, Journal of Crop and Weed. 2014; 10(2):500-503.

17. Singh VK, Shukla AK, Dwivedi BS, Singh MP, Majumdar K, Kumar V et al. Site-specific nutrient management under rice-based cropping systems in IndoGangetic Plains: yield, profit and apparent nutrient balance. Agric Res. 2015; 4:365-377.

18. Yadav MP, Tiwari US, Raj J. Studies on site specific nutrient management (SSNM) for maximization of yield and economics in hybrid rice (Oryza sativa). Plant Archives. 2008; 7(2):795-798. 